Journal of Life Economics

Cilt / Volume 7, Sayı / Issue 1, 2020, pp. 29-40

E - ISSN: 2148-4139

URL: https://www.ratingacademy.com.tr/ojs/index.php/jlecon

DOİ: https://doi.org/10.15637/jlecon.7.003

Araştırma Makalesi/Research Article

\title{
THE ROLE OF KNOWLEDGE MANAGEMENT AGAINST THE PERFORMANCE OF THE PLANT FISH PROCESSING FACTORY IN THE BITUNG CITY
}

\author{
Irvan TRANG * \& Sri MURNI ** \& Lisbeth MANANEKE *** \\ * Economic and Business Faculty Sam Ratulangi University, \\ Manado, INDONESIA, e-mail: trang_irvan@yahoo.com \\ ORCID ID: : https://orcid.org/0000-0003-0772-2308 \\ ** Economic and Business Faculty Sam Ratulangi University, \\ Manado, INDONESIA, e-mail: srimurnirustandi@unsrat.ac.id \\ ORCID ID: https://orcid.org/0000-0002-0292-0869 \\ *** Economic and Business Faculty Sam Ratulangi University, \\ Manado, INDONESIA, e-mail: lisbeth_mananeke@yahoo.com \\ ORCID ID: https://orcid.org/0000-0002-3936-697X
}

\section{ABSTRACT}

The purpose of doing research is to analyze and assess and to develop a variable and instrument to identify the role of knowledge management of the performance of the plants fish processing in the bitung city. Special target to be achieved in this research namely improving the performance of the plant fish processing in the bitung city to improving the economic growth. Next, methods used in the research and approach are observation, included to indentify in this plant fish processing in the Bitung City, using metrode survey, share the survey/ and provide open questionnaire to get accurate results then process of the data and evaluate the results to conference and international published.

After the results obtained, then all this research will give a positive contribution for all stakeholders (academition, businessman, government) where this fits in with a master plan Sam Ratulangi University. This research result indicates that knowledge management had a positive impact and significantly to the performance of the plant fish processing in the Bitung City

Keywords: Knowledge Management, Company Performance, Bitung City

Jel Codes: M00, M11, M15, M19 


\section{INTRODUCTION}

Companies will be exposed to the unique challenge in making strategy which can be used as the basic to optimize the utilization of their resources, both the who are made of Tangible and intangible. Today knowledge into that things is even more important, and through out history, victory always have those who are on the front row in science. Hence the organization currently inclined to the organization knowledge based characterized by the use of intensive information and awareness as a source of to attract consumers. The same raised by Sangkala (2007) that, if organization want to handed to organization that knowledge based, then knowledge management into an optional approach to be made. This causes organization have to manage knowledge and developed it effectively, so as to be the main organization to create wealth organization.

This is in line with an expression of Drucker (1998) who is very well known, namely: the basic economic resource is not longer capital, or natural resources, not labor, it is and will be knowledge. A changing world this leads to the phenomenon that the main source of economic is not longer in the capital form of money or natural resources, but toward the knowledge capital. Because knowledge had an important role in the future, management needs to be a more intensive. A view based knowledges (knowledge-based view) to consider a resource of knowledge as strategic of a corporation, Grant (1996). Kogut and Zander (1993) also indicated that in literature strategic management, a view based knowledge knowledgebased view which the company focus development at resource of knowledge as the most important in creating excellence in sustainable competitiveness. Sangkala (2007) also stated that capital knowledge company / organization is a source to create a solution to Innovation by the organization to continue to change, because of the landscape of competition gets tougher increase important role of a recognition of knowledge in the organization to compete effectively in competition and business environment, based on knowledge organizations need to change values organization and set a new focus through the creation and use of intellectual assets so that we can improve organization performance. This reason the studies to observe how big the impact of the increase of its knowledge management in the organisational performance. It is based on a gap phenomenon in the field, as: This is in line with what happened in the city bitung where there are many plants fish processing declining its performance. Data show it, that there is 10.800 employee who idle due to its death fish processing industries and there are 3,200 boat crews (crew members) lay offs are. More bizarre when there are the fact that the industries fish processing in the city bitung have brought fish of muara baru, Jakarta and some again in import (bisnis.com, 2018). Next, data from jakarta maritime and fishery north Sulawesi show catches of the fish along 2018 is decreasing or we can say that dropped 59,38\%. Since, the number of landing a fish on 2016 reached 111.315,53 tons, while in 2017 only 45.208,52 tons. Resulting from conditions of these conditions and the production of fishery market in north Sulawesi was trapped very in up dropped $80 \%$ than in the normal situation, while several years earlier fish processing industries in north Sulawesi still contraction $30 \%$. Based on valid data recorded that potential fisheries in the city of bitung is in the province of north Sulawesi very large so if in fact and put to good use so could boost the economic growth and created many job opportunities, but by and the fact over the past several years has not done so yet, so that it is our understanding that based on identification of the phenomena of should be made research with the saw the importance of the role of knowledge management to a significant increase in the performance of the plants factory owners who were employing fish that is in the city of bitung, this means that knowledge management who nice and exact will be able to improve the performance of from the factories for the manufacture of fish and as can contribute to the national economic growth. Forward the retreat of the fish processing the factories in the city of bitung cannot be separated from the support of the academics and other stakeholders in who 
sees clear from the side of the importance of the role of the knowledge management in improving the performance of the plant factories in the village.

\section{LITERATURES REVIEW}

Human resource management is the strategic approach to the effective management of people in a company or organization such that they help their business gain a competitive advantage. The overall purpose of human resources is to ensure that the organization is able to achieve success through people

\subsection{Human Resources Management (Human Capital)}

Malayu S.P Hasibuan, (2007 : 6) argues that the management of human resources are the science and art of governing relations and the role of labor to be effective and efficient way to help maintaining the company. According to Dessler (2011:5) human resource management is the policy and practice determine the man or on human resource management positions, including recruiting, filter, train, give incentive and Assessment. The company or organization certainly wish that all the time has high-quality human resources in the sense of meet the requirements of competence to be used in an effort to reach merealisasi vision and short-term and medium-term goals.

\subsubsection{Functions of Management}

In the structure of resources management functions in carrying out men job. According to Sunyoto (2012: 4-6), Managerial function :

a. Planning, program covering the human resources will help the achievement of a goal a company that has set

b. Organizing, is form of various organization with designed the arrangement of the relation between office, personnel, physical and factors

c. Direction, is hold and comparing the observation of the well, take a correction if there is any digression or if necessary adjust again plan which has been made.

\section{Operational Function:}

a. Procurement, involving planning human resources, the recruitment of selection placement and orientation, employees the quality of planning and employee numbers

b. Development, aims to improve skills, knowledge and the attitude of employees in order to carry out their tasks

c. Compensation, can be defined as the award are fair and well for employees in return organization

d. Integration, these include effort employees integration to harmonize the interest of employees, the organization and the community. This venture we need to understand the attitudes and feelings of employees for consideration in the decision makers

e. Maintenance, not just about it his business to prevent loss of employees but referred to with taking care of the measures and the behaviour between them to cooperate and the ability of work the employee

f. Discontinuance of employment relation, is decided it would buy back a working relationship which major ones are the following hang it up and retire, the dismissal of the sacking 


\subsection{Knowledge Management}

Knowledge management is the process of creating, sharing, using and managing the knowledge and information of an organisation. It refers to a multidisciplinary approach to achieving organisational objectives by making the best use of knowledge

\subsubsection{Knowledge Management Development Theory}

Knowledge management is the discipline that was growing up that conceptually can be learned with three approaches namely: (1) organizational cognition and intelligence; (2) organizational strategy and development; and (3) organizational information system and information processing, ilustrated following in the figure 2.1 :

Figure 2.1 Knowledge Management Development Theory

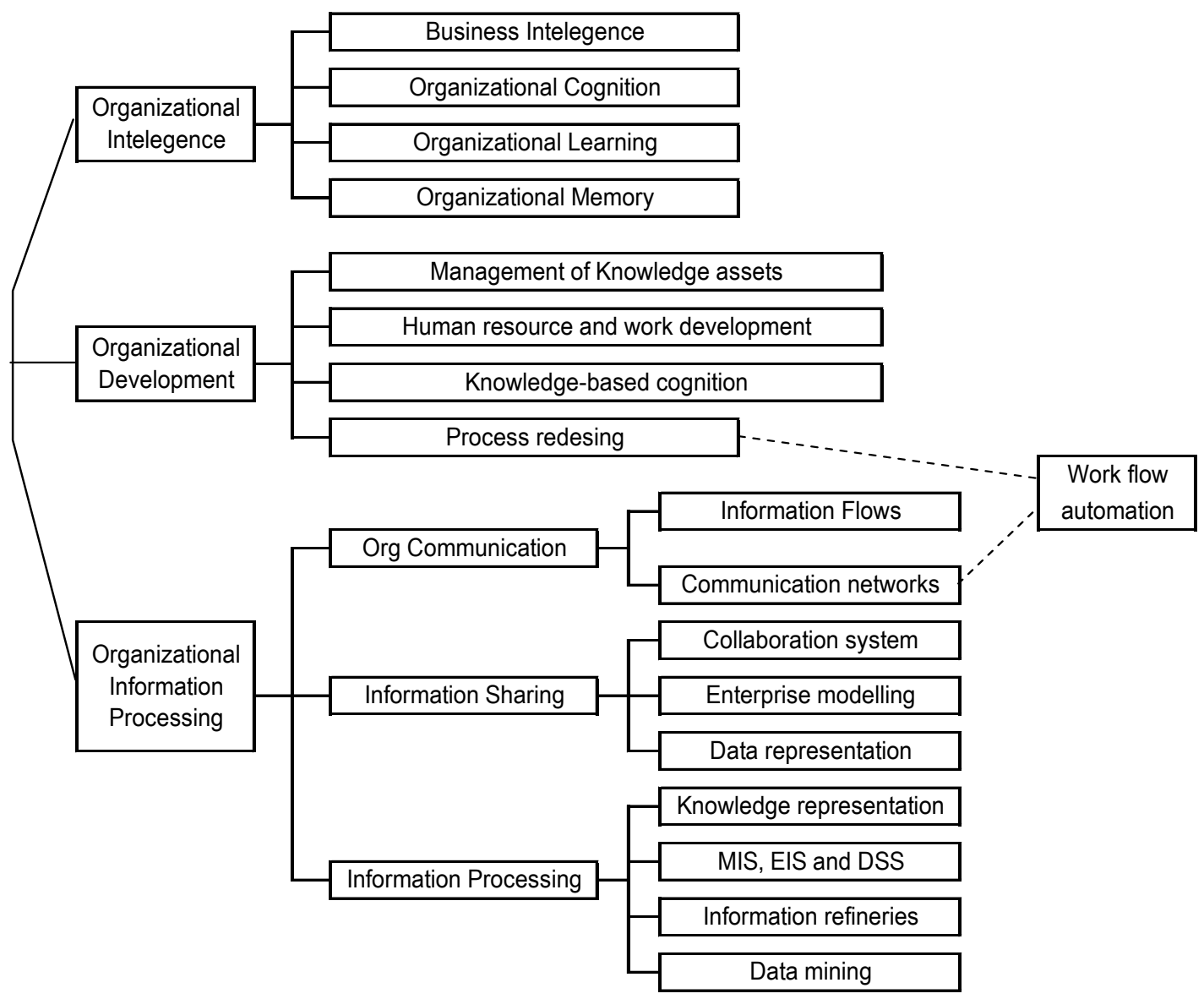

Source: Nurmandi dan Priyono, (2006)

Picture above show discipline of Knowledge Management who reviewed and quoted (Nurmandi and Priyono, 2006), of a book written by Tuomi (1999) corporate called knowledge, theory and practice of organizational intelligent. But year 2002, Tuomi renew his writings in science Journal called the future of management knowledge and quoted by Sangkala (2007). Tuomi own discipline knowledge management divide into four parts, processing the company information, business intelligence, organization cognition and organization development. The development of the theory of knowledge management developed in this research was organational development. Where discipline information processing company rooted in computer technology, based on the information business intelligence, cognition company rooted in innovation company, learning and making sense, while corporate development rooted in business strategies and management of human resources 


\subsubsection{Knowledge Management And Activity}

The term knowledge management first introduced in 1996, in europe, management conference (Tjakraatmadja and Lantu, 2006 / American productivity and quality centre, 1996). This concept but is expanding rapidly and draw attention to many parties. Knowledge management is a concept that has many aspects and has suffered controversy in the debate as long as this (Greiner, 2007). Experts from the field of philosophy and various other discipline has debated the meaning of the definition and dimensions of the knowledge and knowledge management (Nonaka and Takeuchi 1995). Management is the opinion that knowledge is ca not happened and the changes in the environment the globalization in competition, speed information and aging knowledge, old knowledge, the process whereby knowledge into obsolete useless, capital product innovation and processes and competition through market buyers (Picot, 1998). The point, knowledge management activities is organization in managing knowledge as assets, where in various strategic knowledge right are released to the right in the rapid, until they go hand interact, share knowledge and applicated in the day work to improve the organisational performance

Hidayat T, (2007) stated that knowledge management are process of changing knowledge be explicit knowledge or knowledge that readily communicated and documented. Basically knowledge is personal, developed from the experience that is hard to formulated and coordination. Based on they so tacit knowledge are classified as personal knowledge or in other words the knowledge gained from individual (individuals). While expilcit knowledge is formal and systematic that is easy to communicated and divided (Carrillo et al. 2004; Sangkala, 2007; Tobing, 2007; Tjakraatmadja and Lantu, 2006; Lendy, 2005)

\subsection{The Performance Of The Plant}

Performance a term derived from a job performance or actual performance (work performance or achievements surely reached). Performance is a work in quality and quantity reached an employee in carried out in accordance with the responsibilities given (Anwar Prabu Mangkunegara, 2001 : 67). The company (organizational performance) is a picture of the level of achievement of the performance of duties in an enterprise in the pursuit of target the purpose of the company, vision and mission in other words the work achieved organization (Bastian, 2001)

Figure 2.2 Improving The Performance Of The Plant Models

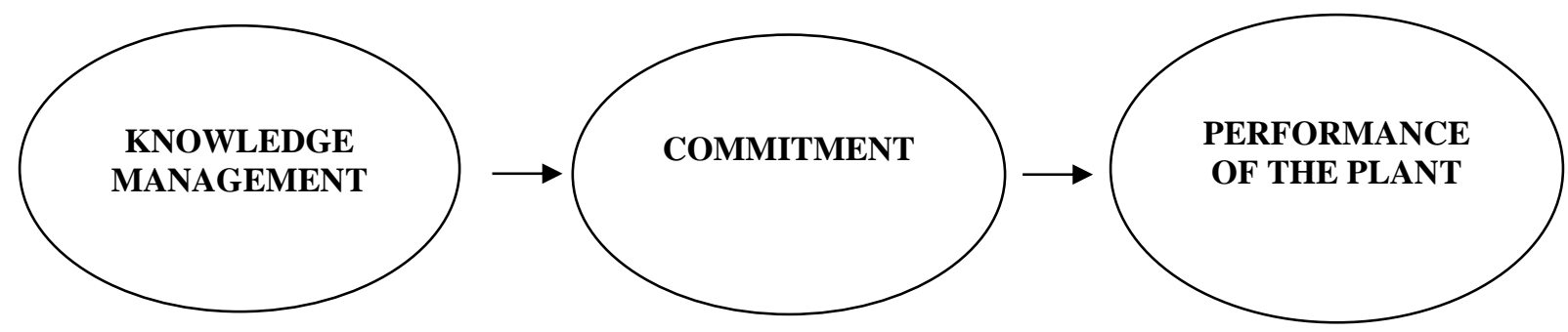

Source: Mangkunegara, (2001)

As for the study and research is being done by researchers namely, the influence of the entrepreneurial attitude, the entrepreneurial of social environment, the entrepreneurial of ability, against the entrepreneurial intensity to be young entrepreneur on kabupaten Minahasa, parent where the research indicated that entrepreneurial of attitude and social environment and the ability is makes perception of someone to be young entrepreneur in developing or launch a new business. 
This is proven with the result that research shows that all three the variable simultaneously influential and have an impact positive significant impact on entreprenuerial intensity, entreprenuerial Attitude, entreprenuerial social environment and the entreprenuerial ability if be noticed contribute positive in encouraging intensity or intention the community to be young entrepreneur in Kabupaten Minahasa, so that the central government should or local utility have to take third this factor to increase the national economic growth thoroughly. Then, research titled career development on entrepreneurial performance in kecamatan Pineleng (2018), where the outcome of this research give essential information about the development of entrepreneur careers in sub district Pineleng

\section{HYPOTHESIS}

Based on the existing problems so hypothesis in this research was Knowledge Management expected have played a role a significant impact on the performance of the plants fish processing in Bitung City, by describing model research as follows :

Figure 2.3. Models

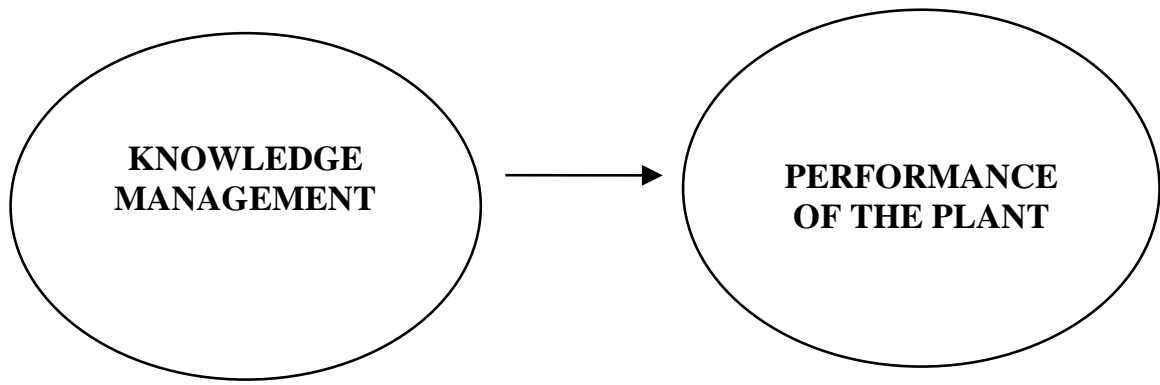

Source: Research, (2019)

\section{RESEARCH METHOD}

Research methodology is the specific procedures or techniques used to identify, select, process, and analyze information about a topic. In a research paper, the methodology section allows the reader to critically evaluate a study's overall validity and reliability

\subsection{Approach Research}

Research by this kind of explanatory research describing a causal relation between variables one other variables with hypothesis (Sugiyono, 2013). Based on it, this study provides an explanation Roles or Influence Knowledge Management to the performance of the plants fish Processing factory in the Bitung City

\subsection{Location And Timing Of Research}

Research is located in a mill fish processing factory bitung city the province of North Sulawesi. The choice of research location based in the multitude of factories for the manufacture of a fish that is productive

\subsection{The Population And Sample}

Population constitute a whole of the subject of study. In this research being the subject of the population is plant fish processing in Bitung City. Sample is part of a population of and characteristic of owned. Samples to be taken of the population have to actually representative (represent), so that the result of research obtained in conclusion will can be implemented for a population (Sugiyono, 2013). Population in research it is all plant fish processing in Bitung City. Next, technique the sample used is sample saturated in which all population are only 
sampled, criteria sample used as respondents were all leaders fish processing plant that is there Bitung. Set respondents came from all leaders plant that is there Bitung.

\subsection{Data Collection Method}

In this research the kind of data that will be used seen from the source was primary and secondary data. Primary data is the data on obtained of a method of interviews and the questionnaire/chief. Secondary data obtained from media intermediaries, obtained and recorded the other hand in generally took the form of evidence, notes or report histories who has are arranged in archive data documentary will all published and not published (Indrianto, 2010). While technique data collection in this research uses the method the spread of the questionnaire/chief, observation and interview

\subsection{Data Analysis}

Linear regression multiple is just as the method of analysis that research involving one variable are believed to be associated with one or more variables free. The object is to predicts changes to the response to variable bound to several variables free (Hair et.al, 1995, in Yamin and Kurniawan, 2009).

\section{RESULTS AND DISCUSSIONS}

In this research express some of his own research, among other:

\subsection{Research Result (Research Object)}

The city of bitung is one city in North Sulawesi. This city has quickly because there is the port to speed development. Bitung city located in north eastern Minahasa land. Municipalities Bitung consisting of land area at the foot of the mountain two brothers and an island called lembeh. Many city bitung that come from the sanger, so that culture is in bitung related to culture in the north Nusa. The city is the capital of Bitung, industry especially fisheries industry. According to historical stories, a name Bitung derived from the name of a tree (oncosperma tigillarium. obs. o filamentosum; nibung) much grown in an area of northern Jazirah Sulawesi island. The first is that gives the name of Bitung Dotu Hermanus Sompotan in the area called Tundu'an or a leader. Dotu Hermanus Sompotan are not alone for this but at that moment he would come along earlier with Dotu Rotti, Dotu Wullur, Dotu Ganda, Dotu Katuuk, Dotu Lengkong. And to know intelligent discernment dotu said was a person who were means to give priority to in or on also could be called as a title of leadership that we are doing at the time it had, same as the use of a word Datuk for the peoples in Sumatra. They are all recognized with name 6 Dotu Tumani Bitung, they opened as well as draw on the area in order to become the regions where they are worthy of to be occupied, they all come from out of the tribe of Minahasa also admits that a certain degree of ethnic Tonsea.

This new coastal areas there are other attract people to come and live settled so that eventually the inhabitants of Bitung. Began to rise before becoming, city Bitung is just a village led by Arklaus Sompotan as the old law (heads first ) village Bitung and lead in more or less 25 years, who at that time is included in the Bitung Village Sub of district Kauditan. From about to 1940-an, entrepreneurs operate marine fisheries Sulawesi interested in existence Bitung than kema (in the north Minahasa now) which was port trade, because according to their views bitung more strategic and could be a substitute kema port. With the advent of bitung as a a strategic region and the number of people who has been increased with a speedy so based on government regulation No. 4 Years 1975 on april 10 Years 1975 bitung can be developed into the tourism and launched as a first administrative in Indonesia

Located in the city of bitung geographical position of $1^{\circ} 23^{\prime} 23^{\prime \prime}-1^{\circ} 35^{\prime} 39^{\prime \prime} \mathrm{LU}$ and $125^{\circ} 1^{\prime} 43^{\prime \prime}-125^{\circ} 18^{\prime} 13^{\prime \prime}$ BT and From the aspect of topografis, most of the city hilly wavy 
bitung 45,06 percent, a mountainous 32,73 percent, land sloping 4,18 percent and wavy 18,03 percent. In the eastern coastal aertembaga ranging from to in western, red cape is the relatively flat with a slope $0-150$, so physically as urban areas can be developed, industry trade and services. In the northern part of the state of progressively undulating and mountainous, agriculture which is a region, plantation, forest zoo and. natural heritage in the southern part of the island is that the soil conditions lembeh generally covered by crude oil plant, horticulture and palawija. In addition to the beautiful coast have the potential of that may be developed into the tourism.

The city of Bitung consisting of eight sub districts:
1. Aertembaga
2. Girian
3. Lembeh Selatan
4. Lembeh Utara
5. Madidir
6. Maesa
7. Matuari
8. Ranowulu

The majority of the people of the city Bitung sprang from the tribe Minahasa and the half-tribe of Sangihe. There were also a great chinese ethnic community in Bitung. Those newcomers who sprang from the tribe and the half-tribe of gorontalo Java, Minangkabau tribe, the tribe of Bitung of aceh found in which most of them as a traders. There are also immigrants from Maluku the ground as well as in Bitung due to flood victims in a city of extremist violence in line. The majority of the people of the city bitung protestant embraced the christian faith. The majority of the people of the city bitung derived from ethnic java and gorontalo convert to Islam. The catholic are also many embraced by the people of the city bitung, while religion konghucu and buddhism many adopted by the derived from chinese ethnic. Language often used by city people bitung is the language of Manado as a mother tongue of the majority of the population city bitung. Language sangihe also often used by a community of sangir that is there bitung. Culture that is there bitung much influenced by the sangihe and talaud culture, because the number of derived from ethnic sangir. An example of culture sangir and talaud that is in bitung namely masamper. Masamper a combination of singing and a little dance that contains about, advice petuah, also words of praise to the lord. Other sangir culture that can be found in the tulude. Tulude derived from a suhude which means turning. Mean a customary ceremony menulude is praise the lord duata / ruata, thank for god protection tourism objects in Bitung North Sulawesi.

But with progress in the industrial sector turned out to develop rapidly and reach the highest value. It is staggeringly the industrial sector really help the economy especially with the spread of employment opportunities. An increase in industrial companies also increasing the welfare of the population especially with absorbedly a workforce of 21.755 , people increase from last year that retention reached 21.290 labor. So also in terms of kapital in which increased the number of this company followed by an increase in investment value be 541,67 billion rupiah increased 23,47 percent than last year. In 2004 transport and communication sector contributes most large in the economy in the Bitung city.

Industries in bitung city in domination by aquaculture industry shipbuilding and industry coconut oil. Besides we have industry transportation sea, food, steel, medium enterprises and small industry of land transportation bitung is there is microfinance as city transport and buses 
as intercity public transport, route, such as bus Bitung - Manado bitung - tondano, bitung gorontalo, bitung - tolitoli and bitung - palu. As a port city, transportation to bitung city sufficient. Transportation bitung of connecting the the mainland and an island bitung lembeh. pelabuhan consisting of passengers and port container port. PT. Pelindo IV Bitung keeps a town more advanced economic is going to be opened and for international as the east gate. Port bitung is the only port in north Sulawesi routes and frequently by passenger vessels between big cities in Indonesia and international. Let alone bitung city one of the by the government as the area special economic exclusive. In the bitung city there are many industrial / plants fishes of both registered clearly in the industry and trading town of Bitung and had not been registered and have only been plants fish processing plant home (possibly seasonal).

\subsection{Regression Analysis Linear Multiple}

Based on the results of using SPSS Program as in the tables below it can be seen that obtained was that regression models :

Table 5.1. Multiple Linear Regression Analysis

\begin{tabular}{|l|r|r|}
\hline \multirow{2}{*}{ Model } & \multicolumn{2}{c|}{ Unstandardized Coefficients } \\
\cline { 2 - 3 } & \multicolumn{1}{|c|}{ B } & \multicolumn{1}{c|}{ Std. Error } \\
\hline 1 (Constant) & 10,331 & 1,867 \\
\hline Knowledge Management &, 223 &, 065 \\
\hline
\end{tabular}

Source: Data Processed, 2019

Regression Equation :

$\mathrm{Y}=10,331+0,223 \mathrm{X}+\mathrm{e}$

Shows that independent variable knowledge management in the model regressions can 37 be expressed if one of the independent variable changed one and other constant, then the dependent variable the performance of the plants to coefficients value of the independent variable value.

The constant as much as 10,331 has given understanding that if knowledge management in unison or together not undergo a change or equal to zero and the size of the the performance of the plants as much as 10,331 . If value $b_{1}$ that is the regression coefficient of knowledge management as much as 0,223 which means have a positive influence on dependent variables means that if variable knowledge management unit added 1, so the performance of the plants there will be supported of 0,223 a unit of assuming other variables fixed or constant.

\subsection{Correlation Coefficient $(R)$ and The Coefficient of Determination $\left(R^{2}\right)$}

Table 5.2. Multiple Linear Regression

\begin{tabular}{|l|r|r|r|r|r|}
\hline \multicolumn{8}{|c|}{ Model Summary } \\
\hline Model & R & R Square & $\begin{array}{c}\text { Adjusted R } \\
\text { Square }\end{array}$ & $\begin{array}{c}\text { Std. Error of the } \\
\text { Estimate }\end{array}$ & Durbin-Watson \\
\hline 1 &, $467^{\mathrm{a}}$ &, 218 &, 209 & 2,295 & 1,429 \\
\hline
\end{tabular}

a. Predictors: (Constant), $\mathrm{X}$

b. Dependent Variable: Y

Source : Data Processed, 2019 
Based on the calculation on using program assistance spss 20 one in table above seen that the $\mathrm{r}$ (was) produced 0,467 and have the strong relationship. $\mathrm{R}$ value square is 0,218 or 21,8 $\%$ meaning influence on variables free: Knowledge Management on variables independent the performance of the plant was $21,8 \%$ and the rest of 0,782 or $78,2 \%$ in influence to other variables

\subsection{Discussion}

\section{The Role of Nnowledge Management On The Performance Of The Plants Fish Processing Factory In The City Of Bitung}

Knowledge management is an organization factory fish processing that is in the bitung city in managing knowledge as an asset, where in a variety of his strategy is the distribution of knowledge that right to the right people and for a quick, until they can interact, share knowledge and apply them in work sehari-hari for improving the performance of the factory, it is proven by the presence of the research shows that the variable significantly effect and have a positive impact on performance factory fish processing factory in the city of bitung

Knowledge management with an indicator standard socialization, externalization, combination, internalization can play role to have a positive impact on the increase in the performance of the plants factories for the manufacture of fish that is in the city of bitung, so that the central government should or local utility should pay attention to the fourth factor this sector fisheries in order to enhance good growth at the local level (Bitung city) or in urban National (Indonesia)

By applying the socialization of comprehensive knowledge management on workers, fish processing factory then the application of unified system that involves, government regulations to combate knowledge management information technology and practices in the field as well as internalization of the application of the attitude at work will provide significant impact on improving the performance of the factory which includes input for the factory, fish processing the outer covering output in the number of production of good and fogging, fish canning the results of outcome both in quality and quantity as well as the impact from an operational has been implemented.

The result of this research secured a second contract from that knowledge management play an important role in improving the performance of the plants factory fish that is in the city of bitung information in spite of the results of additional data / supporters that are found that there are still a lot of factors to other factor that complicated the performance of the plants fish processing factory in the city of bitung has not yet been optimized, one of the examples was by the presence of supply the number of the raw materials required (fish) that more to the decreasing number of the day, fish processing industries in Bitung north Sulawesi experienced a lack of the raw material supply is also due to fish sold fishermen more expensive than the price of the commission which business operators.

The inconsistency between the price set the industry trigger fishermen bitung send supply of fish to the island of Java. This resulted in the selling data the catch in the city declining, bitung while productivity clean fishery in north Sulawesi have actually increased of marine and fisheries north Sulawesi is currently seeking a settlement with the preparation of local regulations to ensure the smooth operation of in the field of fisheries and maritime.

There is also the weather, a monopoly, the emergence of this were the factory home fish are not registered is the factors causing the also in the performance of the plant fish processing. On the other hand, financial capacity of the fish processing a company is not prepared yet to pay of their supplies of fish in cash to fishermen. So that many of the doers an industry that borrow when buying and disadvantage. Need some kind of working capital credit futures 
(standby loan) to get competitively priced with a other fish to fill factory. The need for training on fishermen to provide understanding of the type and of the qualities of fish to be supplied to the mill, thus the application of knowledge management is really needed to that goal.

So far, fishers still sells fish in spindles, leading to the need a sorting catch training for fishermen. To aquaculture industry to face the challenges heavier forward. Globally, fisheries industry are especially canning decreased. The cause, plant to producing canning 24 hours so efficient, while resources can keep fish never happen because depend on the (temporary). Hence, import as options and can be done only when a substitute for when is needed.

If industry / fish processing plant in the city bitung want to meet up the supply, so have to the bold compete with have to price in Java. It is certainly should be paid attention serious than related ministries (government) to provide solutions so the performance of the plants fish processing plant in the city bitung can be maintanance, sustainability and can be had some positive effect later in the National Economic Growth

\section{CONCLUSIONS \& LIMITATIONS}

The research and discussion on so a conclusion can be drawn that knowledge management it has some positive effects significant on fish processing factories performance in Bitung City

\section{CONTRIBUTIONS}

Based on the research results and conclusions research found some findings, so that researchers make some advice. That suggestion among other things as follows (1) knowledge management role or influence in increasing the performance of factories fish processing in the bitung city. Is expected in fish processing factories is in the Bitung city so always use a combination of true knowledge theoretical and practical to each worker. Factors and this question is very important and should be paid attention in order to increase performance factories fishery market that is there bitung, (2) these findings it can be used to science development of human capital related to assess performance (apraisal performance), (3) for research is limited to certain variables, we need further investigated other study associated with this research that has an effect on performance factories fish processing, this is because there are many other factors which has identified and need to development 


\section{REFERENCES}

BASTIAN. (2001), Human Capital and Organizational Performance: A literture review. University of Cambridge

BISNIS. COM. (2018), The fish processing factories in North Sulawesi, Bitung City

DESSLER, G., (2011), Human Resources Management. Jakarta: Indeks Publisher.

DRUCKER. (1998), The Dicipline of Innovation dalam Harvard Business. Review, November - December

GRANT, R.M. (1996), Prospering in Dynamically-Competitive Environments: Organizatonal Capability As Knowledge Integration, Organizational Science. 71(4): 375-387

GRANT, R.M. (1996), Toward a Knowledge Based Theory of The Firm, Strategic Management Journal, 17: 109-122

HASIBUAN. (2005), Human Resources Management. Revised Edition. Jakarta : Bumi Aksara

HASIBUAN. (2007), Human Resources Management. 9 Edition, Jakarta : PT. Bumi Aksara

HIDAYAT, T. (2007), Be learner. Warta ISEI Semarang, August 2 Edition, Page. 11-13

KOGUT, B. and ZANDER, U. (1993), Knowledge of the Firm and the Evolutionary Theory and the Multinational Corporation, Journal of International Business Studies, 24(4): 625-645

MANGKUNEGARA, A.P., (2004), Human Resources Management. The company first casting, PT. Remaja Sodakarya Publisher, Bandung

NONAKA, I. and TAKEUCHI, H. (1995), The Knowledge - Creating Company, New York, NY: Oxford University Press

NURMANDI, A dan Priyono, U. (2006), Knowledge Management Implementation On Public Organization (Theory And Case). Yogyakarta: Sinergi Publishing \& Bandiklat Prof. DIY

SANGKALA. (2007), Knowledge Management, An organization Managing Introductory Understand How to Become an Organization That Superior Knowledge, PT. Raja Grafindo. Persada. Jakarta

SUGIYONO. (2013), Qualitative and Quantitative Research Methodology and R\&D, Bandung: Alfabeta

TUOMI, L. (1999), Corporate Knowledge: Theory and Practice of Intelligent Orgnizations, Metaxis Arkandiankatu Finland

WIDAYANA, L. (2005), Knowledge Management: Increase the Competitiveness of Business, Banyumedia Publishing 